\title{
Stents in the femoropopliteal territory: prevalence of fractures and their consequences
}

\section{Stents no território fêmoro-popliteo: prevalência de fraturas e suas consequências}

Marcelo de Azevedo Daher ${ }^{1}[0$; Gaudencio Espinosa Lopez, TCBC-RJ'; Pedro Vaz Duarte1.

\begin{abstract}
A B S T R A C T
Endovascular treatment for femoropopliteal arterial disease has made revascularization procedures less invasive, but the self-expanding stents used can suffer great wear in arteries with extreme mobility. Objective: to evaluate the prevalence of fractures in stents implanted in the femoropopliteal segment, to identify predisposing factors and consequences on arterial patency. Method: between March and June 2019, thirty patients previously operated for femoropopliteal obstruction underwent stent X-rays in anteroposterior and lateral views to detect fractures and Doppler to analyze arterial patency. Results: we observed 12 cases with fractures (33.3\%): 1 type I ( $2.8 \%), 3$ type II (8.3\%), 5 type III (13.9\%), 3 type IV (8.3\%) and no type V. According to the TASC II we had 1 in group B (8.3\%), 6 in group C (50\%) and 5 in group D $(41.6 \%) p<0.004$. The number of stents per limb was $3.1( \pm 1.3)$ in cases of fracture versus $2.3( \pm 1.3)$ in cases without fracture $(p=0.08)$. The extension was $274.17 \mathrm{~mm}( \pm 100.94)$ in cases of fracture and $230.83 \mathrm{~mm}( \pm 135.44)$ in cases without fracture $(p$ $=0.29$ ). On Doppler we had: 17 patients $(47.2 \%)$ without stenosis, 9 patients $(25 \%)$ with stenosis> 50\% and 10 patients $(27.8 \%)$ with occlusion $(p=0.37)$. There was no correlation between fracture and arterial obstruction $(p=0.33)$. Conclusion: stent fractures are a frequent finding in the femoropopliteal area (33.3\%), being more prevalent in cases of more advanced disease (C and D). There was no association between the finding of fracture and arterial obstruction.
\end{abstract}

Keywords: Stents. Self Expandable Metallic Stents. Angioplasty. Peripheral Arterial Disease. Femoral Artery.

\section{INTRODUCTION}

T he femoropopliteal segment is affected in about $50 \%$ of patients with peripheral arterial disease. The environment of low flow and high local resistance allows the formation of long and diffuse lesions that cause obstructions or occlusions along this section'.

Femoropopliteal obstruction leads to physical disability that can start with symptoms/signs ranging from intermittent claudication, through pain at rest, opening of ulceration, gangrene, which may progress to partial amputation, and even limb loss.

Data show that asymptomatic intermittent claudication is more common than symptomatic claudication in the general population. As age increases and the world population ages, there will be an increase in the total incidence of this disease. It is more common and more severe among men, and the related risk factors are the same for coronary heart disease and cerebrovascular disease, as well as diabetes mellitus².

Ischemia of the lower limbs is the most common arterial disease in the daily routine of the vascular surgeon. In a Brazilian series, Ristow et al. reported, in 3,254 cases treated surgically in twenty years, a 2:1 ratio of men to women, with an average age of 69 years, $63 \%$ of whom were diabetic ${ }^{3}$.

Treatment using minimally invasive techniques started in 1974, when Gruentzig et al. used a device with a distensible balloon at the tip to perform angioplasty in the coronary arteries, at a distance ${ }^{4}$. But Palmaz, in 1987, was the first to implant a balloon-mounted stent for the treatment of a 74-year-old patient with iliac obstruction and disabling claudication. The result was satisfactory, with normalization of the ankle-arm index (ABI) and complete improvement of ischemic symptoms ${ }^{5}$.

This has brought great advances in the treatment

1 - Hospital Universitário Clementino Fraga Filho - UFRJ, Departamento de Cirurgia Vascular Periférica - Rio de Janeiro - RJ - Brasil 
of femoropopliteal obstructive disease, making procedures less invasive, decreasing the length of hospital stay, avoiding large open operations, and leading to a significant drop in perioperative morbidity and mortality rates.

However, as time went by, new problems arose. Complications of endovascular treatment started to be related to the puncture site, to the angioplasty site, to the distal vessel, and systemic. Complications related to the angioplasty site, which are the ones of interest in the present study, can be acute or delayed. The acute ones occur more commonly due to technical failure, such as intima dissection and arterial perforation. Late ones are usually secondary to restenosis, which can culminate in thrombosis of the lumen 6 .

Recently, we have seen material fatigue and stent fractures as a frequent complication in the femoropopliteal segment. The consequences can be restenosis, thrombosis, formation of pseudoaneurysm, and distal embolization?

The femoropopliteal segment presents certain particularities, which make treatment with the implantation of nitinol stents especially problematic. The superficial femoral artery is proximally fixed by the femoral sheath in the region of the inguinal canal, and distally, in the Hunter's canal. The intermediate portion crosses the entire muscular path of the thigh without fixation, undergoing the action of this strong muscular framework, as well as shortening, stretching, twisting and angulation actions resulting from the hip and knee joint movements. Therefore, metallic arterial devices would also suffer from this "excessive" movement of the lower limb, resulting in material wear and subsequent mesh rupture (Figure 1).

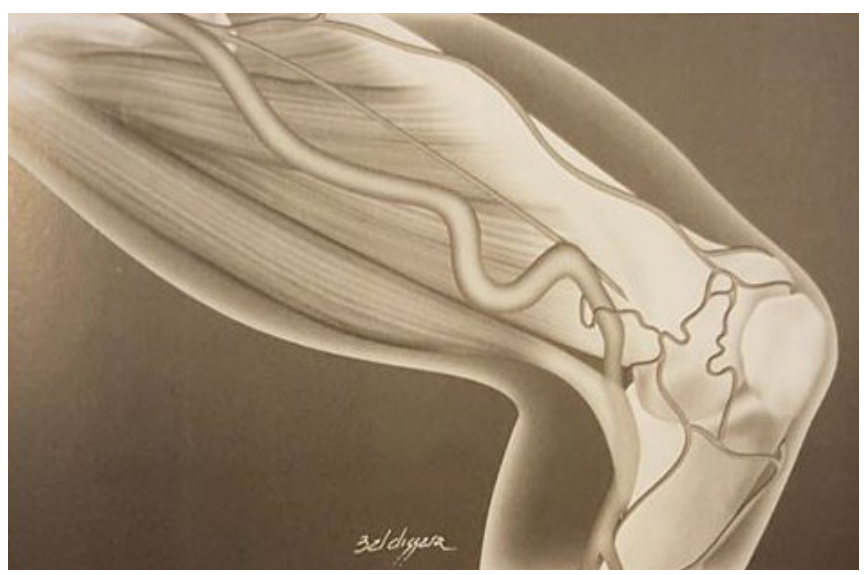

Figure 1. Alteration of the superficial femoral artery conformity during hip and knee flexion. Source: Lobato AC, Araújo AP, Pereira AH. Cirurgia endovascular. São Paulo: ICVESP; 2006.
These fractures in the stent meshes result in the disruption of the architecture's structure and new foci of endothelial irritation can start along the treated area, amplifying the hyperplastic endothelial reaction, precipitating areas of stenosis, decreased flow, ultimately leading to arterial thrombosis.

The objectives of this study are to assess the prevalence of fractures in stents implanted in the femoropopliteal arterial segment, to identify possible predisposing factors, and the possible consequences on the arterial flow.

\section{METHODS}

We carried out the present study at the Vascular Surgery Service of Clementino Fraga Filho University Hospital / UFRJ. We analyzed the medical records of patients undergoing femoral and popliteal angioplasty for peripheral arterial obstructive disease from March to July 2019. We excluded patients who died and who suffered limb amputation. We contacted patients and submitted them to simple radiography of the femoral stents in two incidences (anteroposterior and lateral) for the detection of fractures of the metallic mesh, and to a Doppler ultrasound study, to check the flow of the vessels, as well as the distal arterial drainage.

The study was registered with the Certificate of Appreciation for Ethical Presentation (CAAE) number 04951118.8.00005257 and approved by the hospital's Ethics in Research Committee (CAE), opinion number 3.184.823.

All participants signed a free and informed consent form (ICF), according to the resolution of the National Health Council (CNS) number 466 of 2012.

We selected thirty patients for postoperative follow-up of femoral angioplasty, with a mean follow-up of 67.9 ( \pm 29.0$)$ months. Thirty-six limbs were operated and ninety-one stents were used, with an average of 2.53 $( \pm 1.3)$ stents per limb.

We use simple radiographs in two incidences, anteroposterior and lateral, of the femoral stents. To note the continuity solutions in the stent meshes, following the classification proposed by Jeff et al. 8,9.

These patients underwent a Doppler ultrasound study and were evaluated for stent flow. 
We initially classified obstruction into three groups, namely, without stenosis, stenosis $\geq 50 \%$, and occlusion. We later reclassified these same groups to another new definition: without stenosis versus stenosis $\geq$ $50 \%$ joined with occlusion.

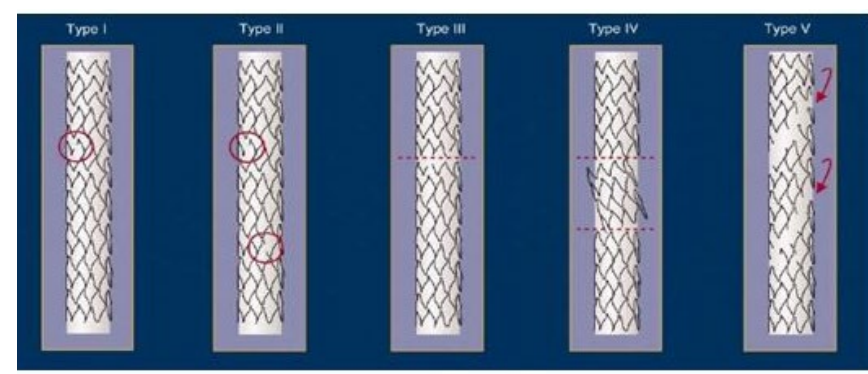

Figure 2. Types of stent fractures.

We recorded information on sex, age, profession, presence of diabetes mellitus, smoking, coronary disease, chronic kidney disease, Rutherford classification before and after the procedures, TASC II classification, postoperative time, operated limb, number of stents used, extension covered by stents, location (proximal, middle and distal thirds of the femoral artery), and the presence of arterial calcification visible on plain radiography.

We fed the patient's data into Excel $\AA$ spreadsheets, and later exported them to the Statistical Package for the Social Sciences Sciences (SPSS - v14.0).

We compared the data distributed according to proportions using the chi-square test (Fisher or Yates, as needed).

We compared interval or ratio data with the ANOVA test, by comparing multiple groups, according to the Tamhane statistics, since the variances between the groups were not homogeneous.

When comparing the same patient (before and after the intervention), we used the paired t-test. We considered differences with errors below $5 \%$ to be statistically significant.

\section{RESULTS}

Regarding the characterization of the study population, there were 14 male patients (46.7\%), 16 female patients (53.3\%), 14 diabetics (46.7\%), 22 smokers (73.3\%), 20 patients with coronary disease $(66.7 \%)$, and two with chronic kidney disease (6.7\%).
There was no statistical significance between the incidence of stent fractures in any of the demographic characteristics above, with $p=0.70$ for sex, $p=1.00$ for diabetes mellitus, $p=0.20$ for smoking, $p=0.11$ for coronary disease, and $p=0.52$ for the presence of chronic kidney disease (Table 1).

The mean age of the patients was $71.3( \pm 9.7)$ years. However, comparing the averages of the interval variables with the presence of fracture, we found that the mean age was $67.5( \pm 8.0)$ years for patients who presented fractures versus $73.4( \pm 10.2)$ for the ones that $\operatorname{did}$ not $(p=0.09)$.

According to Rutherford's clinical classification, the majority of patients concentrated between the classifications comprising disabling claudication and minimal tissue loss in the preoperative period, evolving to asymptomatic to mild claudication, indicating substantial general improvement after the endovascular treatment.

As for the local characteristics related to the stent implantation side, there were 21 (58.3\%) cases of stents implanted in the right lower limb and 15 (41.7\%) in the left lower limb, and in six cases the implant was bilateral.

We divided the femoral artery into three thirds, classifying the implant as locating into these three regions: proximal, middle and distal. When separately analyzing the location in relation to the incidence of fractures, we observed $41.1 \%$ of the cases with fracture in the proximal location ( $p=0.48), 40.7 \%$ in the middle one $(p=0.22)$, $28.5 \%$ distal fractures $(p=0.40)$, and fracture in all locations in $33.3 \%(p=1.00)$.

Regarding the severity of the disease as defined by the Inter-Society Consensus for the Management of Peripheral Arterial Disease (TASC II), there were three cases of TASC A (8.3\%), 11 of TASC B (30.5\%), 13 of TASC C (36.11\%), and 9 TASC D cases $(25 \%)$.

When comparing the groups and assigning values to the disease severity degrees (TASC), the average of patients with fractures was $3.3( \pm 0.7)$ versus $2.5( \pm 0.9)$ of patients without fracture $(p<0.004)$, indicating more cases of fractures in the most severe disease degrees.

There were 20 (55.5\%) procedures on the right lower limb and 16 (44.4\%) on the left lower limb. However, there was no association between the affected side and the presence of fractures $(p=0.50)$. 
Table 1 - Distribution according to characteristics and results.

\begin{tabular}{|c|c|c|c|c|}
\hline \multicolumn{2}{|l|}{ Data } & With Fracture & Without Fracture & $p$ \\
\hline Age & & 67.4 & 73.3 & 0.09 \\
\hline Sex & $\begin{array}{c}\text { Male } \\
\text { Feminine }\end{array}$ & $\begin{array}{l}6 \\
5\end{array}$ & $\begin{array}{c}8 \\
11\end{array}$ & 0.70 \\
\hline Diabetes & $\begin{array}{l}\text { Yes } \\
\text { No }\end{array}$ & $\begin{array}{l}5 \\
6\end{array}$ & $\begin{array}{c}9 \\
10\end{array}$ & 1.00 \\
\hline Smoking & $\begin{array}{l}\text { Yes } \\
\text { No }\end{array}$ & $\begin{array}{c}10 \\
1\end{array}$ & $\begin{array}{c}12 \\
7\end{array}$ & 0.19 \\
\hline Coronary disease & $\begin{array}{l}\text { Yes } \\
\text { No }\end{array}$ & $\begin{array}{l}5 \\
6\end{array}$ & $\begin{array}{c}15 \\
4\end{array}$ & 0.10 \\
\hline CKD & $\begin{array}{l}\text { Yes } \\
\text { No }\end{array}$ & $\begin{array}{c}0 \\
11\end{array}$ & $\begin{array}{c}2 \\
17\end{array}$ & 0.52 \\
\hline Laterality & $\begin{array}{l}\text { RIL } \\
\text { LIL }\end{array}$ & $\begin{array}{l}6 \\
6\end{array}$ & $\begin{array}{c}15 \\
9\end{array}$ & 0.49 \\
\hline Location & $\begin{array}{l}\text { Proximal } \\
\text { Middle } \\
\text { Distal }\end{array}$ & $\begin{array}{c}7 \\
11 \\
8\end{array}$ & $\begin{array}{l}10 \\
16 \\
20\end{array}$ & 0.22 a 0.48 \\
\hline Total femoral coverage & $\begin{array}{l}\text { Yes } \\
\text { No }\end{array}$ & $\begin{array}{l}4 \\
8\end{array}$ & $\begin{array}{c}8 \\
16\end{array}$ & 1.00 \\
\hline Extension of stents & & $274.17 \mathrm{~mm}$ & $230.83 \mathrm{~mm}$ & 0.29 \\
\hline Calcification & $\begin{array}{l}\text { Yes } \\
\text { No }\end{array}$ & $\begin{array}{l}8 \\
4\end{array}$ & $\begin{array}{c}17 \\
7\end{array}$ & 1.00 \\
\hline $\begin{array}{c}\text { Echo Doppler Perviousness } \\
\text { Assessment }\end{array}$ & $\begin{array}{c}\text { No stenosis } \\
\text { Stenosis }>50 \% \\
\text { Occlusion }\end{array}$ & $\begin{array}{l}4 \\
3 \\
5\end{array}$ & $\begin{array}{l}13 \\
6 \\
5\end{array}$ & 0.37 \\
\hline Distal runoff & $\begin{array}{l}1 \text { vessel } \\
2 \text { vessels } \\
3 \text { vessels }\end{array}$ & $\begin{array}{l}3 \\
5 \\
4\end{array}$ & $\begin{array}{l}8 \\
9 \\
7\end{array}$ & 0.21 \\
\hline
\end{tabular}

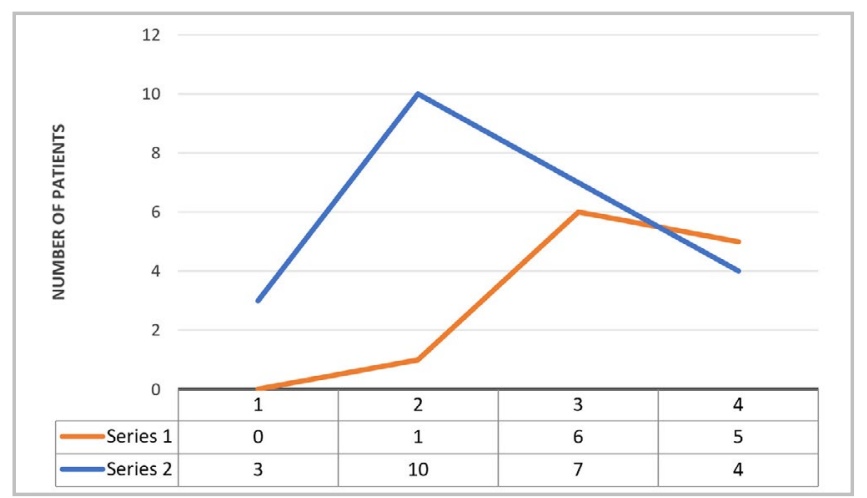

Figure 3. Average distribution of patients according to TASC II. Series 1 : Cases with fracture. Series2 : Cases without fracture.
We analyzed the average number of stents used in each limb and the extent of injury coverage used in each procedure. Similarly, the average number of stents was $3.1( \pm 1.3)$ for limbs that displayed fracture of the material versus $2.3( \pm 1.3)$ for limb that did not show fracture $(p=0.08)$.

We measured the extension of the femoral artery covered by the stents in millimeters and it averaged $274.17 \mathrm{~mm}( \pm 100.94)$ in fracture cases and $230.83 \mathrm{~mm}( \pm 135.44)$ in cases without fracture $(p=$ $0.29)$. 
Twenty-five cases (69.4\%) presented arterial calcification visible on plain radiography, versus 11 (30.6\%) that did not display it. However, there was no association between calcification and the presence of fracture $(p=1.00)$.

There were 12 limbs (33.3\%) with detected fractures: one type I (2.8\%), three type II (8.3\%), five type III (13.9\%), three type IV (8.3\%), and none type V. In 24 limbs (66.7\%), there were no fractures detectable on plain radiography in two incidences, anteroposterior and profile (figure 4).

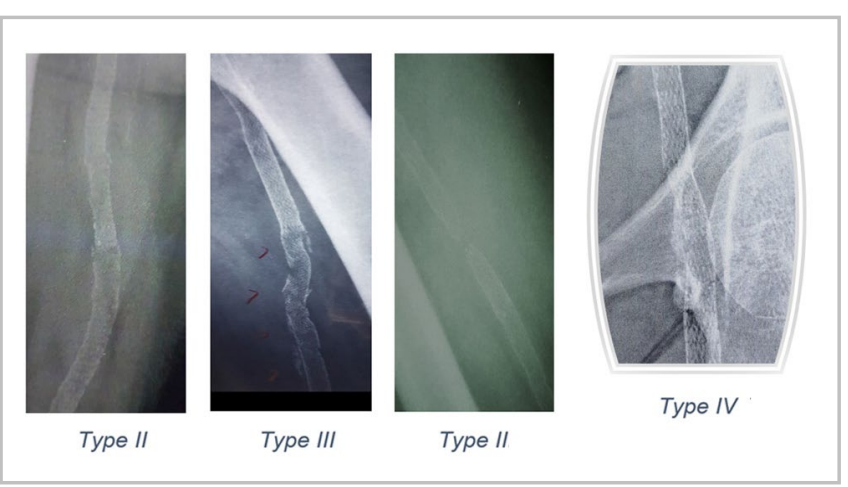

Figure 4. Types of fractures.

Type I (1 broken segment): 1 case; type II (2 or more broken segment): 3 cases; type III (complete section): 5 cases; and type IV (complete section and displacement): 3 cases.
The Doppler exams showed 17 patients $(47.2 \%)$ without stenosis, nine $(25 \%)$ with stenosis > $50 \%$, and ten patients (27.8\%) with occlusion (table 2 ).

When including all the results of the Doppler study (without stenosis, stenosis $>50 \%$ and occlusion), we observed a statistically significant differences ( $p=$ 0.37). However, it is important to note that limbs without stenosis had a lower proportion of fractures (4/17 $23.5 \%)$ than legs with stenosis $>50 \%(3 / 9-33.0 \%)$ or occlusion (5/10 - 50.0\%).

When dividing the results into two groups (with or without obstruction), considering the relatively small sample, we also observed that the group without obstruction presented a lower proportion of fractures $(4 / 17-23.5 \%)$ than the group with partial or total obstruction (8/19 - 42.1\%). Despite an almost twice as large difference, there was no statistically significant difference $(p=0.30)$.

To minimize the impact of fractures on the flow, we also quantified the distal runoff, recording the number of distal vessels in the leg. There were 11 (30.5\%) cases with one distal artery, 14 (38.8\%) with two, and $11(30.5 \%)$ cases with three distal arteries, with $p=0.6$, there being, therefore, no statistical impact on the dependence on distal runoff.

Table 2. Doppler results.

\begin{tabular}{|c|c|c|c|c|c|}
\hline & & & \multicolumn{2}{|c|}{ Fracture } & Total \\
\hline & & & Yes & No & \\
\hline & Without Stenosis & $\begin{array}{l}\mathrm{N}^{\circ} \\
\%\end{array}$ & $\begin{array}{c}4 \\
33.3 \%\end{array}$ & $\begin{array}{c}13 \\
54.2 \%\end{array}$ & $\begin{array}{c}17 \\
47.2 \%\end{array}$ \\
\hline \multirow[t]{3}{*}{ Doppler } & Stenosis > 50\% & $\begin{array}{l}N^{\circ} \\
\%\end{array}$ & $\begin{array}{c}3 \\
25.0 \%\end{array}$ & $\begin{array}{c}6 \\
25.0 \%\end{array}$ & $\begin{array}{c}9 \\
25.0 \%\end{array}$ \\
\hline & Occlusion & $\begin{array}{l}N^{\circ} \\
\%\end{array}$ & $\begin{array}{c}5 \\
41.7 \%\end{array}$ & $\begin{array}{c}5 \\
20.8 \%\end{array}$ & $\begin{array}{c}10 \\
27.8 \%\end{array}$ \\
\hline & Total & $\begin{array}{l}\mathrm{N}^{\circ} \\
\%\end{array}$ & $\begin{array}{c}12 \\
100.0 \%\end{array}$ & $\begin{array}{c}24 \\
100.0 \%\end{array}$ & $\begin{array}{c}36 \\
100.0 \%\end{array}$ \\
\hline
\end{tabular}

The postoperative time was slightly longer in the limbs that displayed a material fracture, 67.9 ( \pm 29.0) months, than in those without fracture, 51.8 ( \pm 28.6) months, though without a statistically significant difference. $(p=0.13)$.

The types of fractures and Doppler results had no influence on the degree of structural impairment of the stent and on arterial flow $(p=0.33)$ (Table 3). 
Table 3. Incidence according to the type of fracture.

\begin{tabular}{|c|c|c|c|}
\hline & \multicolumn{2}{|c|}{ DOPPLER } & Total \\
\hline & Without Obstruction & Partial / Total Obstruction & \\
\hline I & 1 & 0 & $\begin{array}{c}1 \\
(2.8 \%)\end{array}$ \\
\hline II & 0 & 3 & $\begin{array}{c}3 \\
(8.3 \%)\end{array}$ \\
\hline III & 2 & 3 & $\begin{array}{c}5 \\
(13.9 \%)\end{array}$ \\
\hline IV & 1 & 2 & $\begin{array}{c}3 \\
(8.3 \%)\end{array}$ \\
\hline Total & 4 & 8 & $\begin{array}{c}12 \\
(33.3 \%) \\
\end{array}$ \\
\hline
\end{tabular}

\section{DISCUSSION}

There is much controversy about the effects of femoral stent fractures on arterial flow. Several authors report deleterious effects to the flow $8,7,11-14$, while others suggest that there is no damage to the flow of the treated vessel $^{15-20}$

Biomechanical factors contribute to the fatigue of the material due to oxidative stress and excessive movement of the lower limb. The pulsatile arterial flow itself and the small potential difference on the metal surface can cause wear and loss of structural stability, resulting in fracture ${ }^{21}$.

Nikanorov et al. (2008) found the transition between the distal superficial femoral artery and the popliteal artery as the maximum point of axial compression and angulation. These authors also suggest that these forces would result in repetitive local trauma, stimulating inflammation and activating smooth muscle cells of the middle layer ${ }^{22}$.

In an interesting study, Smouse et al. (2005) assessed the mobility of the femoropopliteal segment by performing angiographies on the lower limbs of fourteen cadavers and comparing arteries with and without stent implants. They recorded the films in positions that simulated acts of ambulation, sitting, standing and climbing stairs. Shortening and angulation were the most frequent and important changes. They did not observe stretching and torsion due to the limitations of the study. However, these changes, shortening and angulation, significantly affected the spatial design of the arteries, especially those with implanted stents ${ }^{23}$. lida et al. demonstrated, in a study with forty patients who underwent femoral angioplasty, a higher incidence of stent fracture in the subgroup of patients who walked more than 5,000 steps per day ${ }^{24}$. In our study, we observed a higher incidence of fractures in younger patients than in older patients, with a mean age of $67.5 \pm$ 8.0 versus $73.4 \pm 10.2$ years, respectively. This may indicate that they have a more active life, with greater physical activity than the older ones, therefore more prone to the occurrence of fractures, implying a tendency of association between fracture and younger age, although there was no statistically significant difference $(p=0.09)$.

In another study with cadavers in which the researchers implanted intra-arterial nitinol markers in the femoropopliteal segment, tomography showed greater mean axial compression in the popliteal artery (from $11 \%$ to $25 \% p=0.02$ ) and higher degrees of folding in the adductor hiatus and popliteal artery, compared to the proximal superficial femoral artery $(p<0.05)^{25}$. This is in agreement with the analysis made by Ansari et al, who also demonstrated more significant changes, such as axial shortening, lumen compression and angulation of the distal superficial femoral artery and popliteal artery during walking, climbing stairs and sitting ${ }^{26}$.

In our study, we could not find significant differences regarding the location of stents in the femoropopliteal segment. When we look at the fracture rates for isolated segments of the superficial femoral artery, which are above $40 \%$ in the proximal and middle segments, we see that the lowest absolute fracture rates occurred when there were stents implanted in the three segments, proximal, middle, and distal (12 out of 36$)$, and 
in the distal segment (eight out of 28). In these, there were about $33.3 \%$ and $28.5 \%$, respectively, of fracture rates found. Tomoi et al. found less flow after three years when they had implanted stents in isolated segments (spot stenting) than stents in the entire superficial femoral (full coverage stenting) ${ }^{27}$. There is a possibility that when there is a long extension of assembled and overlapping stents, they function as a single mechanical complex, less subject to deformation actions than when there are bare areas adjacent to areas covered by stents. This can cause interaction between areas that are more rigid and less rigid ones, favoring angulation, twisting and stretching. Studies with cadavers observed this change in axial stiffness close to areas not covered by stents, leading to biomechanical stress and fracture ${ }^{28,23}$. However, a fact evidenced in cadaver samples shows that longitudinal stiffness is greater than circumferential stiffness in the popliteal artery and in the infrapatellar trunks than in the proximal superficial femoral artery. This occurs by changing the direction of the collagen fibers in the arterial wall in the axial direction, compensating for the angulation forces in diseased distal arteries $^{29}$. Theoretically, this would make a long stent segment more stable at the distal end, as it would be interacting with a more rigid longitudinal popliteal artery.

Practically all patients ( $86 \%$ of cases) clustered in the 3 and 5 Rutherford degrees before the procedures, that is, between disabling claudication and minimal tissue loss. In the postoperative period, there was migration to milder degrees, between 0 and 3 (97.1\%), that is, between asymptomatic and disabling claudication, indicating general clinical improvement. However, in the group of patients with fractures, although there was a drop from $3.33( \pm 0.9)$ to $1.25( \pm 1.5)$ in the absolute value in the average Rutherford score, we observed greater mean and standard deviation in the postoperative period of cases with fracture, indicating a lower degree of clinical improvement.

Vascular calcification is a limiting factor for the endovascular technique, in addition to hindering postprocedure arterial remodeling and decreasing post-stent flow rate by increasing residual stenosis. About $30-50 \%$ of patients with peripheral arterial disease have some degree of vascular calcification ${ }^{30}$. We found vascular calcification in $69.4 \%$ of the cases, but there was no association with the presence of fracture $(p=1.00)$.
Endovascular treatment of femoral obstructive disease is performed preferably in cases of localized involvement, in patients with TASC II degrees $A$ and $B^{1,31}$. However, there is a current trend to treat the most severe cases, TASC \| C and D, by the endovascular method initially, since even for conventional open surgery there is a higher rate of reintervention, as shown by Malas et al. These authors demonstrated, in a retrospective study, that patients undergoing bypass had a higher rate of reintervention than the group undergoing stent angioplasty (54\% versus $31 \% p=0.02$ ), and attributed this fact to the severity of patients classified as $C$ and $D^{32}$.

Most studies show that a higher rate of fractures follow treatments performed on injuries $C$ and $D^{16,17,19,20}$. Patients classified as TASC D, mainly female diabetics, with recurrent lesions or chronic total occlusion, are at increased risk of restenosis ${ }^{33}$. Other authors have also demonstrated worse prognosis and lower flow rates in patients with TASC degrees $C$ and $D^{34,35}$.

In our sample, assigning values to categories A, B, C and D, we obtained an average score of 3.3 ( \pm $0.7)$ in cases with fractures versus $2.5( \pm 0.9)$ in those without stent fractures $(p<0.004)$. This proves in fact that advanced disease in the femoropopliteal segment is associated with a higher rate of stent fracture.

Although some studies have reported worse prognosis for females ${ }^{33,34}$, in ours we have not found such an association.

Regarding the affected side, there was no difference in the incidence of fractures between the lower limbs, the right with $28.5 \%$ (6 out of 21 cases) and the left with $40.0 \%$ (6 out of 15 cases) of fractured stents ( $p$ $=0.50$ ).

Scheinert et al. studied the length of the superficial femoral artery covered by the stent, dividing treated segments into three groups: $\leq 80 \mathrm{~mm},>80$ to $160 \mathrm{~mm}$, and $>160 \mathrm{~mm}$, and found a relative frequency of $13.2 \%, 42.4 \%(p=0.05)$ and $52 \%(p<0.0001)$ respectively. This shows that with larger coverage areas, fractures would also be more likely ${ }^{13}$. Lin et al. also found a greater number of fractures in longer occlusions of the treated femoral artery, with a mean of $209.8 \mathrm{~mm} \mathrm{(} \pm$ 114.1), $p=0.05$ (19). In our study, we had an average covered area of $274.17 \mathrm{~mm}( \pm 100.9)$ between cases with fracture and we observed a relative frequency of coverage 
areas of $20 \%<150 \mathrm{~mm}, 55 \% 150300 \mathrm{~mm}$, and $29 \%$ > $300 \mathrm{~mm}, \mathrm{p}=0.1$. We had a higher proportion of fractures in patients with coverages between 150 and $300 \mathrm{~mm}$ in length, which leads us to think like Tomoi et al., who found greater primary flows in patients submitted to full coverage of the femoral artery when compared with the group with partial coverage $(72 \%$ versus $53 \%, p=$ $0.014)^{27}$. Most authors who obtained very low fracture and patency rates had stents implanted in short areas, usually smaller than $100 \mathrm{~mm}^{36-38}$.

The average number of stents used was lower in the legs that did not have a fracture than in those with one $(2.3 \pm 1.3$ versus $3.1 \pm 1.3, p=0.08)$. An interesting "in vitro" study by Høl et al. showed that in stent overlays, under pulsatile flow and low potential difference, there is greater metal corrosion than in single stents ${ }^{21}$. Despite this finding, our study showed that in cases where long segments were treated there were fewer fractures, perhaps indicating that the interaction of stents with each other is not the only cause of wear. On the other hand, other local anatomical factors may contribute to the stabilization of the endoprosthetic complex in the arterial lumen, reducing the wear of the mesh and the fracture rate.

The Doppler study is the exam of choice for the surveillance of conventional or endovascular revascularization procedures, as it is low-cost, non-invasive and easily reproducible. We observed a lower proportion of fractures in the group without obstruction on Doppler (4 out of 17 cases, $23.5 \%$ ) than in the groups in which there was obstruction or occlusion (8 out of 19 cases, $42.1 \%$ ). Although there was no statistical significance ( $p$
$=0.3)$, the difference is almost twice as large.

It is known that the distal runoff influences the stent's patency rate. Analyzing the average distal vessels between patients with and without fracture $(2.08 \pm$ 0.7 versus $1.96 \pm 0.8$ ), we did not observe a statistically significant difference $(p=0.6)$, which reduces the bias in the analysis and interpretation of stent patency.

We found no evidence that the postoperative time had an influence on the wear of the material, which makes us think that once well adapted to the individual local anatomical characteristics, the stent will display less wear and fracture rate.

Regarding the type of fracture, we observed a greater number of type II and III fractures, eight cases out of $12(66 \%)$, and a higher rate of flow impairment, that is, six out of eight stents (75\%) with stenosis / occlusion. This fact contrasts with data from the literature that suggest that simpler fractures (I and II) have little clinical significance, while more complex ones (III to $\mathrm{V}$ ) often cause more stenoses ${ }^{12}$.

\section{CONCLUSION}

Stent fractures are a frequent finding in the femoropopliteal sector, reaching $33.3 \%$ of cases in this study. They were more prevalent in cases of more advanced TASC II (C and D). There was no association between the finding of fracture and obstruction or occlusion. However, prospective controlled studies are needed, with a larger number of participants, for a better analysis of the effects of stent fractures on the arterial endothelial bed in the femoropopliteal sector.

\title{
R E S U M O
}

\begin{abstract}
Os tratamentos endovasculares para a doença arterial obstrutiva fêmoro-poplítea tornaram os procedimentos de revascularização menos invasivos, porém os stents metálicos autoexpansíveis utilizados podem sofrer grande desgaste em artérias com extrema mobilidade. Objetivo: Avaliar a prevalência de fraturas em stents implantados no segmento fêmoro-poplíteo, identificar fatores predisponentes e possíveis consequências sobre a patência arterial. Métodos: entre março a junho de 2019, trinta pacientes previamente operados por obstrução fêmoro-poplítea realizaram RX dos stents em incidências ântero-posterior e perfil para detectar fraturas e eco Doppler para analisar a patência arterial. Resultados: observamos 12 casos com fraturas (33,3\%): 1 do tipo I (2,8\%), 3 do tipo II (8,3\%), 5 do tipo III (13,9\%), 3 do tipo IV (8,3\%) e nenhuma tipo V. Segundo a classificação TASC II, tivemos 1 no grupo $B(8,3 \%), 6$ no grupo $C(50 \%)$ e 5 no grupo $D(41,6 \%)$ p $<0,004$. O número de stents por membro foi de $3,1( \pm 1,3)$ nos casos de fratura contra $2,3( \pm 1,3)$ nos casos sem fratura $(p=0,08)$. A extensão tratada foi $274,17 \mathrm{~mm}( \pm 100,94)$ nos casos de fratura $e$ $230,83 \mathrm{~mm}( \pm 135,44)$ nos casos sem fratura $(p=0,29)$. No Doppler tivemos: 17 pacientes $(47,2 \%)$ sem estenose, 9 pacientes $(25 \%)$ com estenose $>50 \%$ e 10 pacientes $(27,8 \%)$ com oclusão $(p=0,37)$. Não houve correlação entre fratura e obstrução arterial ( $p=0,33)$. Conclusão: as fraturas de stents são um achado frequente no setor fêmoro-poplíteo (33,3\%) sendo mais prevalentes nos casos de doença mais avançada TASC II C e D. Não houve associação entre o achado de fratura e obstrução arterial.
\end{abstract}

Palavras chave: Stents. Stents Metálicos Autoexpansíveis. Angioplastia. Doença Arterial Periférica. Artéria Femoral. 


\section{REFERENCES}

1. Zeller T. Current state of endovascular treatment of femoro-popliteal artery disease. Vasc Med. 2007; 12(3):223-34.

2. Criqui $\mathrm{MH}$, Aboyans V. Epidemiology of Peripheral Artery Disease. Circ Res. 2015; 116(9):1509-26.

3. Brito C, Duque A, Merlo I, Murilo R, Lauria V, editores. Cirurgia Vascular: Cirurgia Endovascular, Angiologia. 2a. ed. Rio de Janeiro: Revinter; 2002. 683-684 p.

4. Grüntzig A, Hopff $\mathrm{H}$. [Percutaneous recanalization after chronic arterial occlusion with a new dilator catheter (modification of the Dotter technique)]. Dtsch Med Wochenschr. 1974;99(49):2502-10, 2511. German.

5. Palmaz JC, Richter GM, Nöldge G, Kauffmann GW, Wenz W. [Intraluminal Palmaz stent implantation. The first clinical case report on a balloonexpanded vascular prosthesis]. Radiologe [Internet]. 1987;27(12):560-3. Available from: http:// europepmc.org/abstract/MED/2964053

6. Cronenwett JL, Johnston KW. Rutherford's Vascular Surgery E-Book. Elsevier Health Sciences; 2014.

7. Adlakha S, Sheikh M, Wu J, Burket MW, Pandya U, Colyer W, et al. Stent fracture in the coronary and peripheral arteries. J Interv Cardiol. 2010;23(4):4119.

8. Jaff M, Dake M, Pompa J, Ansel G, Yoder T. Standardized evaluation and reporting of stent fractures in clinical trials of noncoronary devices. Catheter Cardiovasc Interv. 2007; 70(3):460-2.

9. Allie DE, Hebert CJ, Walker CM. Nitinol stent fractures in the SFA. Endovasc Today. 2004;22-34.

10. Rocha-Singh KJ, Zeller T, Jaff MR. Peripheral arterial calcification: Prevalence, mechanism, detection, and clinical implications. Catheter Cardiovasc Interv. 2014;83(6):E212-E220. [cited 2019 Aug 3]; Available from: https://onlinelibrary.wiley.com/doi/ pdf/10.1002/ccd.25387

11. Rits J, van Herwaarden JA, Jahrome AK, Krievins D, Moll FL. The Incidence of Arterial Stent Fractures with Exclusion of Coronary, Aortic, and Non-arterial Settings. Eur J Vasc Endovasc Surg. 2008;36(3):33945 .
12. Hüttl $A B$, Hüttl $A$, Vértes $M$, Nguyen $D T$, Bérczi Á, Hüttl $K$, et al. The presence of long and heavily calcified lesions predisposes for fracture in patients undergoing stenting of the first part of the subclavian artery. J Vasc Surg. 2019; 560-3.

13. Scheinert D, ScheinertS, Sax J, Piorkowski C, Bräunlich $\mathrm{S}$, Ulrich $\mathrm{M}$, et al. Prevalence and clinical impact of stent fractures after femoropopliteal stenting. J Am Coll Cardiol [Internet]. 2005;45(2):312-5. Available from: http://dx.doi.org/10.1016/j.jacc.2004.11.026

14. Sakamoto $Y$, Yamawaki M, Araki Motoharu, Kobayashi N, Mori S, Tsutsumi M, et al. Comparison of 12-month angiographic outcomes between repeat drug-eluting stent implantation and drugcoated balloon treatment for restenotic lesion caused by stent fracture. Heart Vessels [Internet]. [cited 2019 May 5];1:3. Available from: https://doi. org/10.1007/s00380-019-01398-x

15. Ferreira $M$, Lanziotti $L$, Monteiro $M$, Abuhadba G, Capotorto LF, Nolte L, et al. Superficial Femoral Artery Recanalization with Self-expanding Nitinol Stents: Long-term Follow-up Results. Eur J Vasc Endovasc Surg. 2007; 34(6):702-8.

16. lida O, Nanto S, Uematsu M, Ikeoka K, Okamoto $S$, Nagata S. Influence of Stent Fracture on the Long-Term Patency in the Femoro-Popliteal Artery. Experience of 4 Years. JACC Cardiovasc Interv [Internet]. 2009;2(7):665-71. Available from: http:// dx.doi.org/10.1016/j.jcin.2009.04.014

17. Davaine JM, Quérat J, Guyomarch B, Brennan MA, Costargent A, Chaillou $P$, et al. Incidence and the clinical impact of stent fractures after primary stenting for TASC C and D femoropopliteal lesions at 1 year. Eur J Vasc Endovasc Surg [Internet]. 2013;46(2):201-12. Available from: http://dx.doi. org/10.1016/j.ejvs.2013.05.016

18. Babaev AA, Kotwal A, Zavlunova S, Telis A. Stent Fractures in the Superficial Femoral Artery and Restenosis: How Strong Is the Association? J Am Coll Cardiol [Internet]. 2013;61(10):E1809. Available from: http://linkinghub.elsevier.com/retrieve/pii/ S0735109713618094

19. Lin Y, Tang X, Fu W, Kovach R, George JC, Guo $D$. Stent fractures after superficial femoral artery stenting: Risk factors and impact on patency. J 
Endovasc Ther. 2015; 22(3):319-26.

20. Wahab Hagag M, Tawfik A. Stent fracture after provisional stenting using four brands of nitinol stents in trans-atlantic inter-society consensus c and $d$ femoropopliteal lesions: in 1 year's follow-up. Egypt J Surg. 2017; 36(3):283-90.

21. Høl PJ, Gjerdet NR, Jonung T. Corrosion and metal release from overlapping arterial stents under mechanical and electrochemical stress - An experimental study. J Mech Behav Biomed Mater [Internet]. 2019 May 4 [cited 2019 Mar 3];93:315. Available from: http://www.ncbi.nlm.nih.gov/ pubmed/30769231

22. Nikanorov A, Smouse HB, Osman K, Bialas $M$, Shrivastava S, Schwartz LB. Fracture of selfexpanding nitinol stents stressed in vitro under simulated intravascular conditions. J Vasc Surg. 2008; 48(2):435-40.

23. Smouse HB, Nikanorov A, LaFlash D. Biomechanical forces in the femoropopliteal arterial segment. Endovasc Today [Internet]. 2005;(June):60-6. Available from: http://evtoday.com/2005/06/ EVT0605_F3_Smouse.html/

24. Iida O, Nanto S, Uematsu M, Morozumi T, Kotani J ichi, Awata M, et al. Effect of Exercise on Frequency of Stent Fracture in the Superficial Femoral Artery. Am J Cardiol. 2006;98(2):272-4.

25. Poulson $W$, Kamenskiy A, Seas A, Deegan P, Lomneth C, MacTaggart J. Limb flexion-induced axial compression and bending in human femoropopliteal artery segments. J Vasc Surg [Internet]. 2018;67(2):607-13. Available from: https://doi.org/10.1016/j.jvs.2017.01.071

26. Ansari F, Pack LK, Brooks SS, Morrison TM. Design considerations for studies of the biomechanical environment of the femoropopliteal arteries. J Vasc Surg [Internet]. 2013;58(3):804-13. Available from: http://dx.doi.org/10.1016/j.jvs.2013.03.052

27. Tomoi $Y$, Soga $Y$, Takahara $M$, Fujihara $M$, Lida $O$, Kawasaki $D$, et al. Spot stenting versus full coverage stenting after endovascular therapy for femoropopliteal artery lesions. J Vasc Surg [Internet]. 2018 [cited 2019 May 22]; Available from: https:// doi.org/10.1016/j.jvs.2018.12.044

28. Fortier A, Gullapalli V, Mirshams RA. Review of biomechanical studies of arteries and their effect on stent performance. IJC Hear Vessel. 2014;4(1):12-8.

29. Kamenskiy A V., Pipinos II, Dzenis YA, Lomneth CS, Kazmi SAJ, Phillips NY, et al. Passive biaxial mechanical properties and in vivo axial pre-stretch of the diseased human femoropopliteal and tibial arteries. Acta Biomater. 2014; 10(3):1301-13.

30. Rocha-Singh KJ, Zeller T, Jaff MR. Peripheral arterial calcification: Prevalence, mechanism, detection, and clinical implications. Catheter Cardiovasc Interv. 2014;83(6):212-20.

31. Norgren L, Hiatt WR, Dormandy JA, Nehler MR, Harris KA, Fowkes FGR, et al. Inter-Society Consensus for the management of peripheral arterial disease (TASC II). Int Angiol. 2007;26(2):82-157.

32. Malas MB, Enwerem N, Qazi U, Brown B, Schneider $E B$, Reifsnyder $T$, et al. Comparison of surgical bypass with angioplasty and stenting of superficial femoral artery disease. J Vasc Surg. 2014; 59(1):129-35.

33. Iida O, Takahara M, Soga Y, Suzuki K, Hirano K, Kawasaki $D$, et al. Shared and differential factors influencing restenosis following endovascular therapy between TASC (Trans-Atlantic Inter-Society Consensus) II Class $A$ to $C$ and $D$ lesions in the femoropopliteal artery. JACC Cardiovasc Interv. 2014; 7(7):792-8.

34. Biagioni RB, Brandão GD, Biagioni LC, Nasser F, Burihan MC, Ingrund JC. Endovascular treatment of TransAtlantic Inter-Society Consensus II D femoropopliteal lesions in patients with critical limb ischemia. J Vasc Surg [Internet]. 2019;69(5):15108. Available from: https://doi.org/10.1016/j. jvs.2018.08.176

35. Davaine JM, Querat J, Kaladji A, Guyomarch B, Chaillou P, Costargent A, et al. Treatment of TASC C and $D$ femoropoliteal lesions with paclitaxel eluting stents: 12 month results of the STELLA-PTX registry. Eur J Vasc Endovasc Surg. 2015;50(5):631-7.

36. Laird JR, Jain A, Zeller T, Feldman R, Scheinert $D$, Popma JJ, et al. Nitinol Stent Implantation in the Superficial Femoral Artery and Proximal Popliteal Artery: Twelve-Month Results From the Complete SE Multicenter Trial. J Endovasc Ther [Internet]. 2014;21(2):202-12. Available from: http://jet. sagepub.com/lookup/doi/10.1583/13-4548R.1 
37. Ohki T, Angle JF, Yokoi H, Jaff MR, Popma J, Piegari $G$, et al. One-year outcomes of the U.S. and Japanese regulatory trial of the Misago stent for treatment of superficial femoral artery disease (OSPREY study). J Vasc Surg. 2016;63(2):370-376.e1.

Received in: 05/02/2020

Accepted for publication: 16/04/2020

Conflict of interest: no.

Funding source: none.
38. Garcia L, Jaff MR, Metzger C, Sedillo G, Pershad A, Zidar F, et al. Wire-Interwoven Nitinol Stent Outcome in the Superficial Femoral and Proximal Popliteal Arteries: Twelve-Month Results of the SUPERB Trial. Circ Cardiovasc Interv. 2015;8(5):e000937.

\section{Mailing address:}

Marcelo de Azevedo Daher

E-mail: mazdaher@live.com

(त) (1) 